\title{
開口の筋違補 強の研究
}

その1〜せん断力を受ける場合

$\begin{array}{lllll}\text { 正会員 } & \text { 難 } & \text { 波 } & \text { 治 } & \text { 之* } \\ \text { 正会員 } & \text { 佐 } & \text { 藤 } & \text { 勝 } & \text { 利*** }\end{array}$

地下変電所などの深層構造物の床板は, 外壁からの土 圧，水圧の影響を受け，また地震時にせ外壁へせん断力 を伝澾する等のため，大きな二次元應力が生ずる。この ため地上のスラブに比べで厚さが大である。これらの床 板に設備のための開口が設けられるが，開口の影響を若 慮する必要がある。

一般に開口のある板では開口周辺に応力集中が起り， 通常は開口周を鉄笳で補強している。開口の影響の最も 大きい場合はせん断を受ける場合であるが，これの補強 方法として筋違が考えられる。

本論文は，正方形開口のある板の内側境界に荷重を受 ける問題を二次元弾性論により解き，その変位加ら筋違 の作用を荷重で表現して，補強効果を考察したものであ る。をた，光弾性実験により理論の検討を行っている。

\section{§1．対角線筋違による補強}

\section{a）開口の隅に荷重を受ける場合の解}

正方形開口を有する無涱板を表わす曲線座標として

$$
z=a\left(3 e^{w}+0.5 e^{-3 w}\right)
$$

但L, $z=x+i y, w=\alpha+i \beta$

$$
\text { 即方 }\left\{\begin{array}{l}
x=a\left(3 e^{\alpha} \cos \beta+0.5 e^{-3 \alpha} \cos 3 \beta\right) \\
y=a\left(3 e^{\alpha} \sin \beta-0.5 e^{-3 i \alpha} \sin 3 \beta\right)
\end{array}\right.
$$

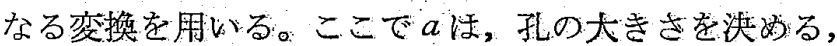
長さの単位の定数である。図一1 わしたものであるが，

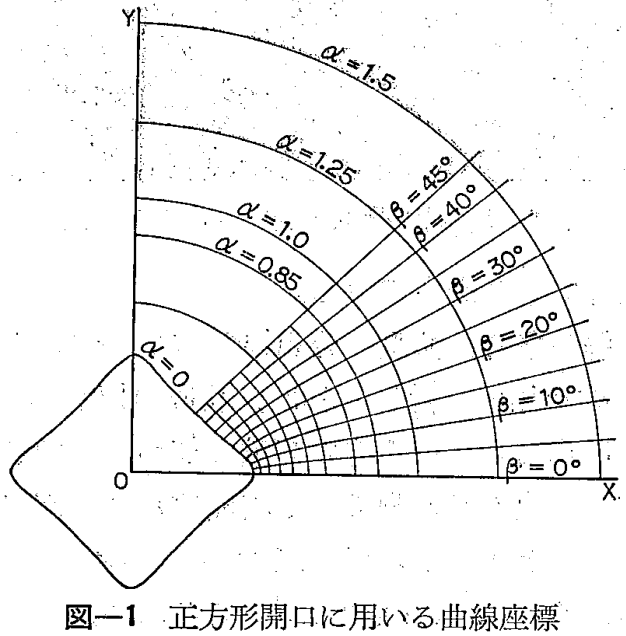

*早稲田大学 大学院生 ** 東電設計株式会社 (昭和 54 年 3 月 31 日本受理 ・討論期涱昭和 56 年 1 月末日)
の長さが $5 a$ の正方形孔に近似している。

応力函数は横田の応力一般式”を用い; 曲線座標に対 する応力の函数 $\varphi_{1}, \varphi_{2}$ を次のように選ぶ。

$$
\left\{\begin{array}{l}
\varphi_{1}=\sum_{n} e^{-n w} \cdot A_{n} \\
\varphi_{2}=\sum_{n} e^{-(n+1) w} \cdot B_{n} \cdot a, n \text { は整数 }
\end{array}\right.
$$

ここで， $A_{n}, B_{n}$ は境界条件から定まる実定数で岕る。 この時, 忘力は

$$
\left\{\begin{array}{l}
\sigma_{\alpha}+\sigma_{\beta}=R_{\varepsilon}\left[\varphi_{1}\right] \\
\sigma_{\alpha}-\sigma_{\beta}-2 i \tau_{\alpha \beta}=\left(i y \frac{d \varphi_{1}}{d w}+\varphi_{2}\right) / \frac{d \bar{z}}{d w}
\end{array}\right.
$$

によって求められ，また， $x, y$ 軸方向の変位 $u, v$ はヤ ング率を $E$, ポアソン比を レとすれば2),

$$
\left\{\begin{aligned}
E u= & -\frac{1+\nu}{2} y I_{m}\left[\varphi_{1}\right]+\frac{1-\nu}{2} R_{e}\left[\int \varphi_{1} d z\right] \\
& +\frac{1+\nu}{2} R_{e}\left[\int \varphi_{2} d w\right] \\
E v= & -\frac{1+\nu}{2} y R_{e}\left[\varphi_{1}\right]+I_{m}\left[\int \varphi_{1} d z\right] \\
& -\frac{1+\nu}{2} I_{m}\left[\int \varphi_{2} d w\right]
\end{aligned}\right.
$$

によって求まる。

境界条件は，筋違からの荷重を 図一2 のように，筋 違と同じ幅をもった，境界に直交方向の等分布何重とみ なしこれをフーリエ級数によって表現する。等分布荷 重の強さを $p$, 荷重の分布幅を決める $\Delta \beta$ を $\Delta \beta=\pi / f$
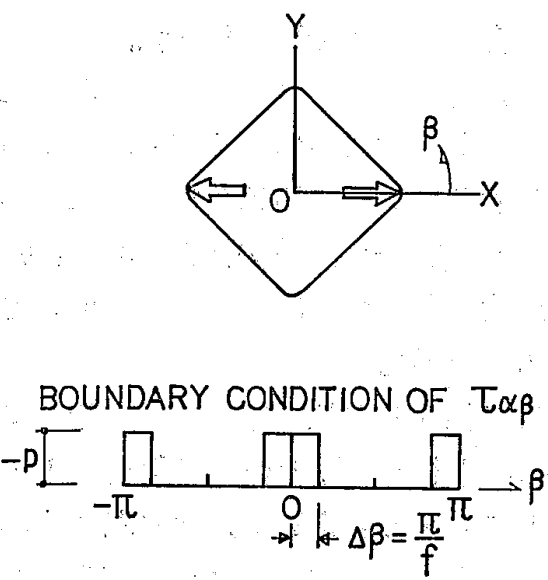

図一2 隅に荷重学受ける時の境界条件 
とすると，孔周に於ける境界条件は次のように表わせ る。

$$
\begin{aligned}
& \alpha=0 \text { にて } \\
& \left\{\begin{array}{l}
\tau_{\alpha \beta}=0 \\
\sigma_{\alpha}=-\frac{2 p}{f}-4 p_{n=2,4,6 \ldots} \frac{1}{n \pi} \sin \frac{n \pi}{f} \cos n \beta
\end{array}\right.
\end{aligned}
$$

更に次式で表わされる無限遠に於讨る境界条件があ る。

$$
\alpha=\infty \text { にて } \sigma_{\alpha}=\sigma_{\beta}=\tau_{\alpha \beta}=0
$$

これらの境界条件を（4）式の左辺に代入乙，右辺は (1)，(3) 式を代入して三角関数に展開すれば,,雨辺の係 数を比較することにより，定数 $A_{n}, B_{n}$ ，決定できる。 はじめに無限遠の条件から

$A_{n}$ の $n$ は $n>0, B_{n}$. $n$ は $n>-2$

であることがわかり，さらに孔周の境界条件から，以下 のよ5に全ての定数が定まる。

$$
\begin{aligned}
A_{2}= & \frac{12 p}{5 \pi} \sin \frac{2 \pi}{f}, A_{4}=\frac{8 p}{f}\left(\frac{f}{4 \pi} \sin \frac{4 \pi}{f}-\frac{1}{2}\right), \\
A_{6}= & 8 p\left(\frac{1}{6 \pi} \sin \frac{6 \pi}{f}-\frac{1}{4 \pi} \sin \frac{2 \pi}{f}\right), \cdots \ldots \\
B_{0}= & 3 A_{2}-\frac{1}{4} A_{4}+\left(1-\frac{f}{8 \pi} \sin \frac{4 \pi}{f}\right) \frac{12}{f} p, \\
B_{2}= & 6 p\left(\frac{1}{2 \pi} \sin \frac{2 \pi}{f}-\frac{1}{6 \pi} \sin \frac{6 \pi}{f}\right) \\
& -\frac{13}{4} A_{2}+6 A_{4}-\frac{3}{4} A_{6}, \cdots \ldots \\
B_{4}= & \frac{6 p}{f}\left(1-\frac{f}{8 \pi} \sin \frac{8 \pi}{f}\right)+\frac{1}{2} A_{2} \\
& -6 A_{4}+9 A_{6}-\frac{5}{4} A_{8}, \cdots \cdots .
\end{aligned}
$$

これらの定数を応力の函数 (3) 式に代大して（4) 式 を用いれば，最終的に応力を求めることができる。図一 3:(a)，(b) 注，境界条件（6）式のフーリエ級数を $n=$ 120 となる項までとり，荷重の分布幅を $\Delta \beta=\pi / 15$ とし た場合の，孔周応； 及び，開口の辺の中央を通りその 辺に垂直な断面（ $\beta=45^{\circ}$ 線上）の せん断応力の分布を 示したものである。単位は $[P / a t]$ となっているが， $P$ は分布荷重の合力， $t$ は板厚を表わす。

写真一1 は，解のチェックのために行なった光弾性実 験で, $5 \mathrm{~mm}$ 厚 D.A.P. 板に, 一辺が $2.5 \mathrm{~cm}$ の正方形孔 をあけ，相対する二久所の隅部をテグスによって $60 \mathrm{~kg}$ で引張っている。図一3 (a) の中のプロットが実験から 求めた孔周応力であるが，理諭と良く一致している。

\section{b）筋違の負担軸力}

開口を筋違で補強した板の応力は，上記の解に，正方

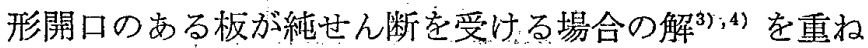
合わせることによって求まるが，その際に筋違の軸力 $P$ を知る必要がある。これは，ふたつの解を重水合わせた 時の開口隅部の相対変位が，筋違の縮多に一致するとい

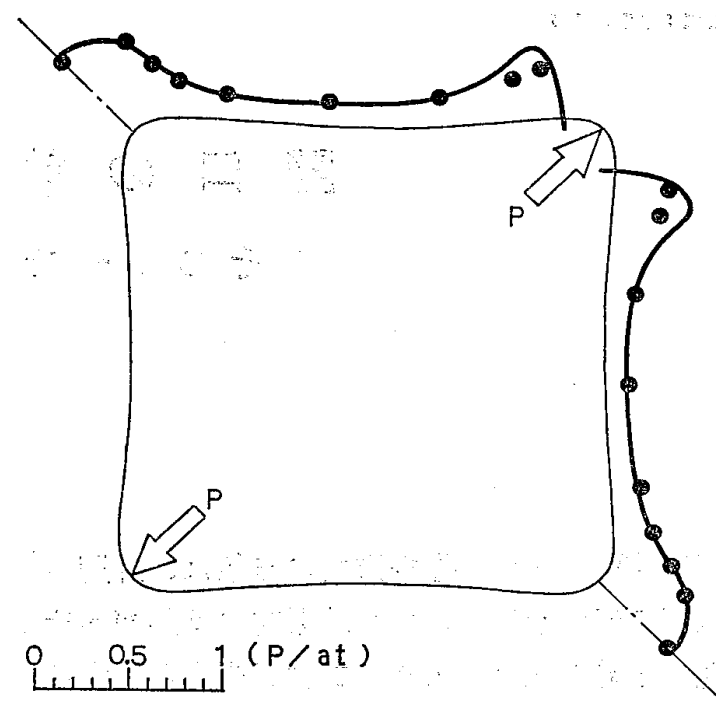

图一3（a）隅代荷重を受ける時の孔周応力分布

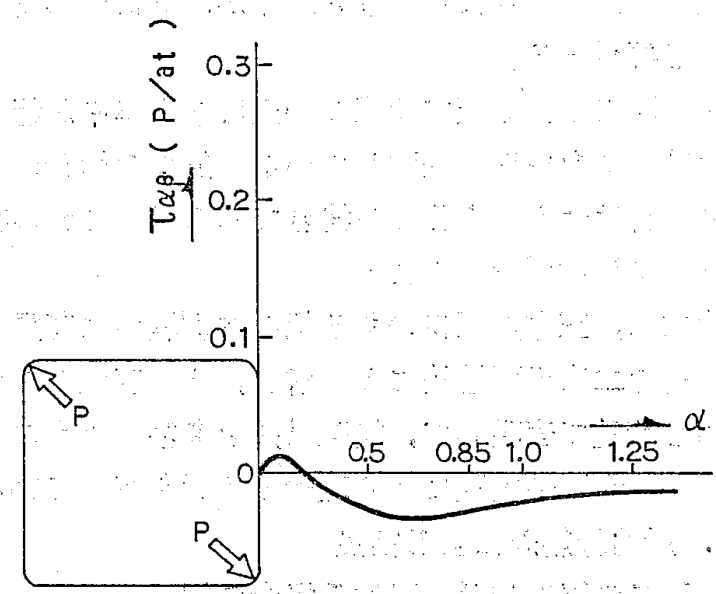

図一-3(b) : 隅に荷重を受ける時の $\beta=45^{\circ}$ 線上の せん断応力分布

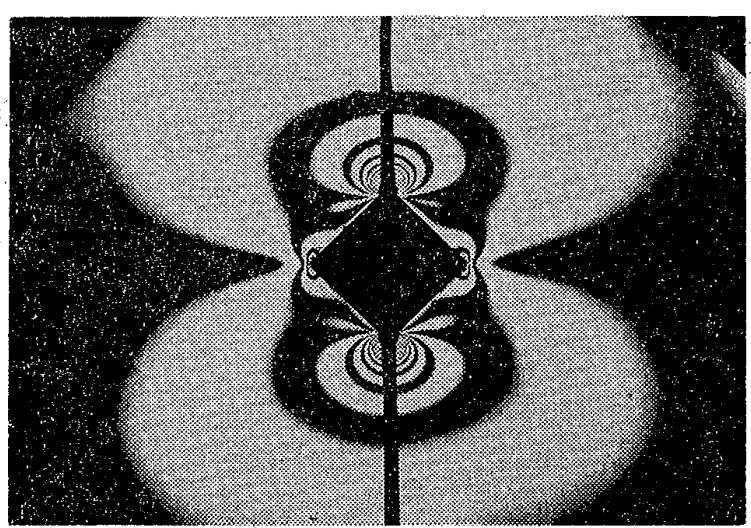

写真一1 隅に荷重を受ける時の等色線

う適合条件により決定できる。

前節の解の場合，荷重の分布幅が $\Delta \beta=\pi / 15$ というこ とは (2) 式を用いで計算寸れば，筋違の幅が $0.66 a$ で 要る場合に相当し，この時の荷重の加わっている開口隅 部の変位（筋違の幅の中での平均変位）は，ポアソン比 を $\nu=0.167$ とすると，(5) 式から，Euう2.04 P/t で あるとわかる。また，純せん断の場合には，同じ部分の

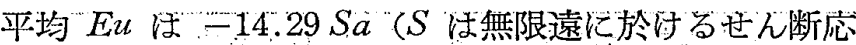
力）である。従って，筋違端部に於ける变位の適合条件 
は，

$$
2(-14.29 S a+2.04 P / t)=-P .7 a / 0.66 a t
$$

となり（ここで $7 a$ は筋違長さ， 0.66 at は筋違断面積 とである)，これを解けば，結局，筋違の軸力は 1.95 Sat 決定される。

\section{c）対角線筋違の効果}

筋違の軸力が求まると，それに応じて a）の解と純せ 儿断の場合の解とを重悋合わせることにより，最終的に 筋違によって補強された有孔板の応力を知ることができ る。図一4（a）の太線が，幅 $0.66 a$ の筋違で補強した 場合の孔周応力分布を示したものであり，細線は比較の ために筋違のない場合の応力を示したものである。これ によると, 孔周态力は, 筋違の存在によって, 筋違のと りついていない開口隅部に於いて減少し，筋違端部に近 ら゙くにつれ今度は逆に増大していることがわかる。そし て, 筋違端部に於いて, 応力は再び減少する傾向が認め られるが，この部分の虑力は，a）の解に於いて，筋違 からの圧力を孔周に直交方向の等分布荷重と仮定したた め, 正しく求めることができない。次の 図一4(b) は，

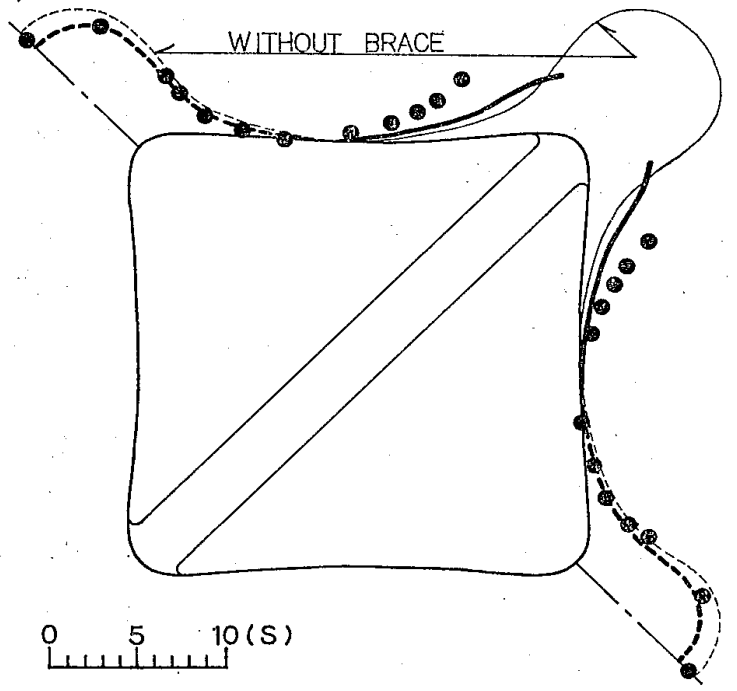

图一4（a）対角線脇違で補強された板の 孔周応力分布

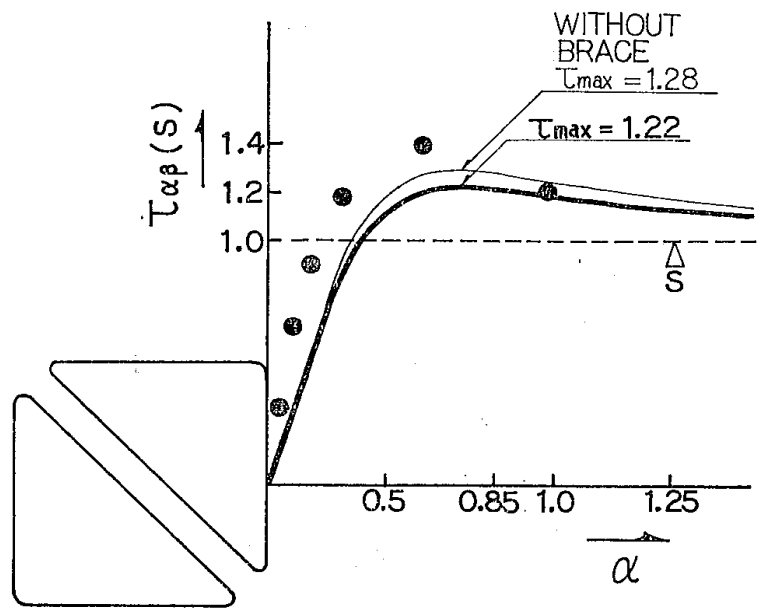

図一4(b) 対角線筋違で補強された板の $\beta=45^{\circ}$ 線上のせん断忘力分布 $\beta=45^{\circ}$ 線上のせん断応力の 分布を示したものである。 筋違夯無いと，この断面上のせん断応力は，開口からや や離れた所に於いて，無開口の時のせん断応力の約 1.28 倍（すなわち $28 \%$ の増大）となるが，幅 $0.66 a$ の筋 違を入れることにより，その増大を $22 \%$ に抑えること ができる。

\section{§2．平行筋違による補強}

\section{a） 開口の辺の中央に荷重を受ける場合の解}

ここでは, 図一5 のように，筋違からの荷重が各辺の 中央に斜めに加わっている場合の解を求めるが，これ は，孔周に於ける境界条件が異なるのみで，\$1．と解法 は同一である。この場合，荷重が境界に対して傾いて作 用しているために，荷重を境界に直交方向の成分と接線 方向の成分とに分け，それぞれをフーリエ級数で表わ す。従って， 81 ， と同椂，等分布荷重の強さを $p$, 荷重 の分布幅を決める $\Delta \beta$ を $\Delta \beta=\pi / f$ とすると，孔周に於 ける境界条件は次式となる。

$$
\begin{aligned}
& \alpha=0 \text { にて } \\
& \left\{\begin{array}{l}
\tau_{\alpha \beta}=-\sum_{m=2,6,10 \ldots} \frac{8 p}{m \pi} \sin \frac{m \pi}{f}(-1)^{\frac{m+2}{4}} \sin m \beta \\
\sigma_{\alpha}=-\frac{4 p}{f}-\sum_{n=4,8,12 \ldots} \frac{8 p}{n \pi} \sin \frac{n \pi}{f}(-1)^{n / 4} \cos n \beta
\end{array}\right.
\end{aligned}
$$

この場合の応力の函数 (3) 式の定数 $A_{n}, B_{n}$ は以下 のごとく求まる。

$$
\begin{aligned}
A_{2}= & \frac{72 p}{5 \pi} \sin \frac{2 \pi}{f}, \\
A_{4}= & -16 p\left(\frac{1}{2 f}+\frac{1}{4 \pi} \sin \frac{4 \pi}{f}\right), \\
A_{6}= & -16 p\left(\frac{1}{4 \pi} \sin \frac{2 \pi}{f}+\frac{1}{6 \pi} \sin \frac{6 \pi}{f}\right) \\
& +\frac{1}{2} A_{2}, \cdots \cdots
\end{aligned}
$$

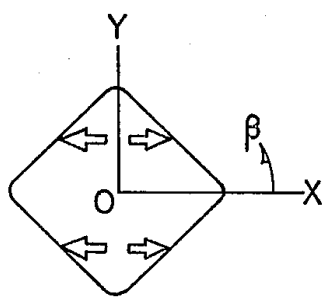

BOUNDARY CONDITION OF $\tau \alpha \beta$

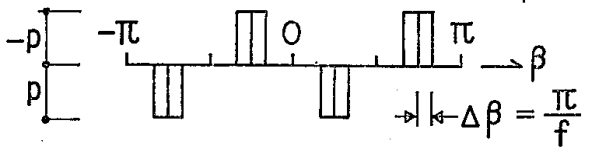

BOUNDARY CONDITION OF $\sigma_{\alpha}$

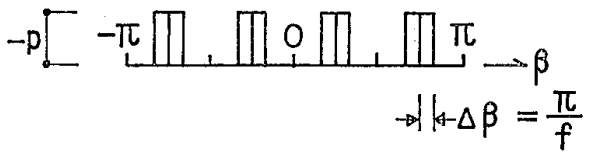

图一5 辺の中央に荷重を受ける時の境界条件 


$$
\begin{aligned}
B_{0}= & 24 p\left(\frac{1}{f}+\frac{1}{8 \pi} \sin \frac{4 \pi}{f}\right)+3 A_{2}-\frac{1}{4} A_{4}, \\
B_{2}= & -24 p\left(\frac{5}{4 \pi} \sin \frac{2 \pi}{f}+\frac{1}{12 \pi} \sin \frac{6 \pi}{f}\right) \\
& -\frac{13}{4} A_{2}+6 A_{4}-\frac{3}{4} A_{6}, \\
B_{4}= & 24 p\left(\frac{1}{2 f}-\frac{1}{16 \pi} \sin \frac{8 \pi}{f}\right)+\frac{1}{2} A_{2}
\end{aligned}
$$

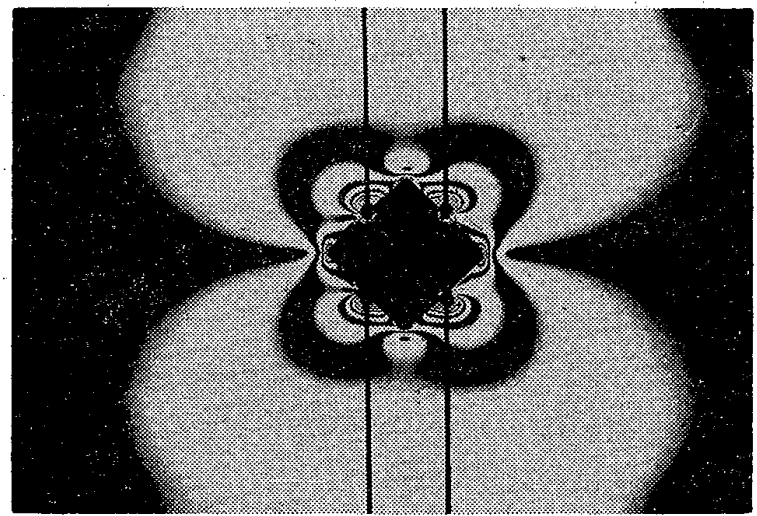

写真一2 辺の中央に荷重を受ける時の等色線

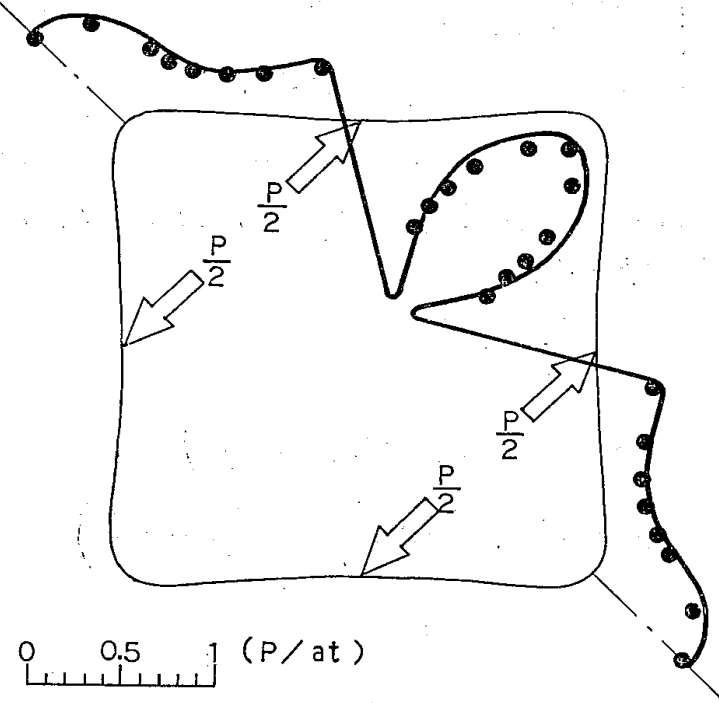

図一6（a）辺の中央に荷重を受ける時の孔周 灾力分布

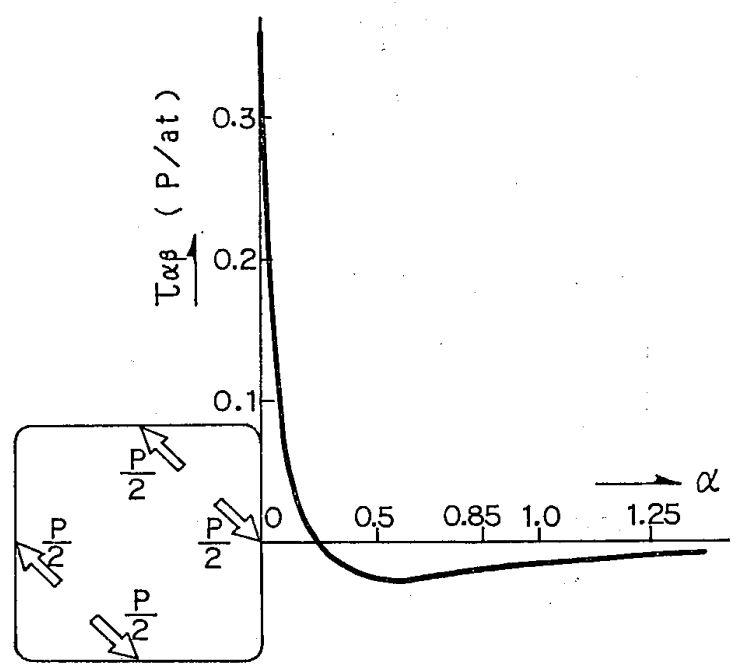

図一6（b）辺の中央に荷重を受ける時の $\beta=$ $45^{\circ}$ 線上のせん断応力分布

$$
-6 A_{4}+9 A_{6}-\frac{5}{4} A_{8}, \cdots \cdots
$$

これらの定数を応力の函数 (3) 式に代入して，(4) 式 を用いれば，応力が求められる。図一6 (a),(b) は，境 界条件（8）式のフーリエ級数を $n=120$ となる項をで とり, 荷重の分布幅を $\Delta \beta=\pi / 30$ とした場合の孔周态 力.: 及び板内部のせん断応力の分布を示したものであ る。（この場合の筋違幅を（2）式により求めてみると， $0.66 a$ となり，これは $\$ 1$.に於いて， $\Delta \beta=\pi / 15$ とし た場合の筋違幅に一致する。)

写真一 2 は, この場合の光弾性実験で, 写真一1 と同 じ試験体の各辺の中央に各箇所 $30 \mathrm{~kg}$ の引張力を加え たものである。図一6 (a) 中のプロットが実験から求め た孔周惢力であるが，理論と良く一致している。

\section{b）筋違の負担軸力}

幅が $0.66 a$ の筋違を 2 本平行に入れた場合について, その負担軸力 $P$ を筋違端部の変位の適合条件により求 めてみると，P=3.84 Sat が得られる。この值は 2 本の 筋違の軸力の和であるから，これを\$1。の結果と比較 してみると, 平行筋違の一本当たりの軸力は, 対角線に 筋違を入れた時の軸力と大差ないことがわかる。

図一7は, 両タイプの筋違について, 筋違の幅を種々 変化させた場合の負担軸力 $P$ の值を示している。

\section{c) 平行筋違の効果}

筋違幅が $0.66 a$ である場合の負担軸力をもとにして, a）の解と純せん断の解とを重社合わせ，平行筋違によ って補強された有孔板の㦄力分布を求めたのが 図一8 (a)，(b) である。図一8(a) の太線がその孔周态力分布 であるが，細線で示された筋違の無い時の応力分布と比 較すると，四隅で応力集中が緩和されている。特に同図 中，左上隅あるい注右下隅での応力集中緩和効果が著し く, 筋違が無い時の灾力に比べると, 約 $29 \%$ の減少と なっている。また，図一8（b） は，板内部のせん断虑力 の分布を示したものであるが，幅 $0.66 a$ の筋違がある と，せん断応力の最大増大率を $19 \%$ に抑えることがで

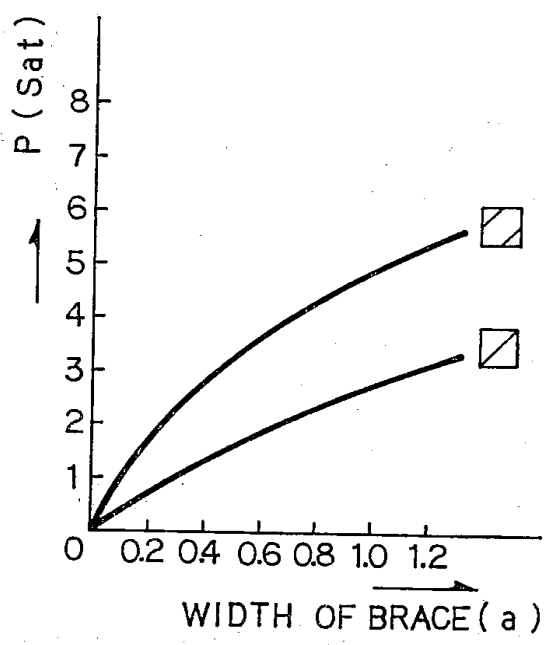

図一7 筋違幅と負担軸力の関係 


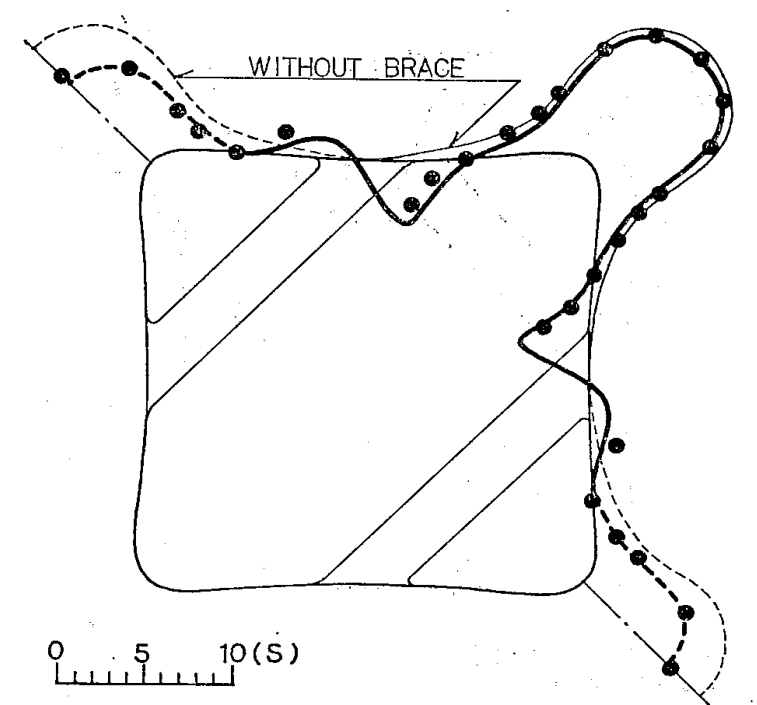

图一8（a）平行筋違で補強された板の孔咅 応力分布

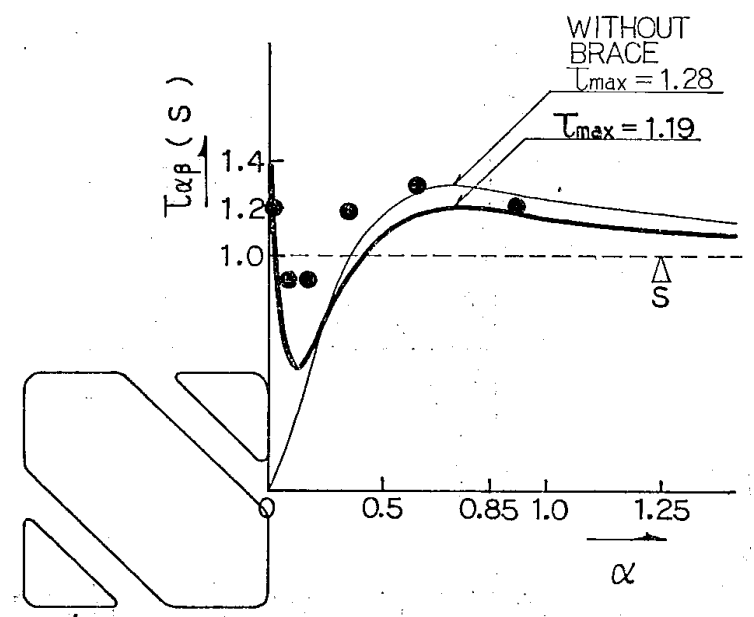

図一-8(b) 平行筋違で補强された板の $\beta=45^{\circ}$ 線上のせん断応力分布

きる。な㧍，筋違端部付近で局部的に増大しているせん 断応力は, 筋違内部に生じている応力の影響によるもの でありこれに対する補強は筋違側の問題である。

\section{§3. X形筋違および菱形筋違による補強}

a). 開口縁に荷重を受ける場合の解

今度㹥筋違を互いに直交する 2 方向に入れた場合につ いて検討する。この場合の筋違の効果の 理論解は\$1.

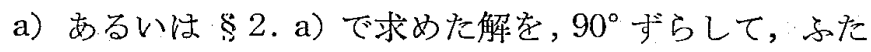

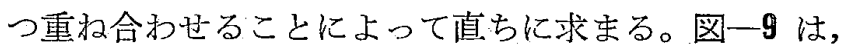
相対する一組の隅に压縮力を受汁，他の隅には引張力が 加わっている場合の孔周応力を示したものであり，また 図一10 は，開口の辺の中央に荷重が加わっている場合 の孔周忘力を示したものである。そして， $\beta=45^{\circ}$ 線上 に於けるせん断応力に関しては, 図一3(b) あるいは 図 一6(b)をただ単に 2 倍すれば良い。

\section{b) 筋違の負担軸力}

筋違端部の変位の適合条件から求好た，X形筋違と菱 形筋違の各場合についての筋違幅と艺の負担軸力 $P$. 関係を 図一11 に示す。ここで責担軸力 $P$ というのは,

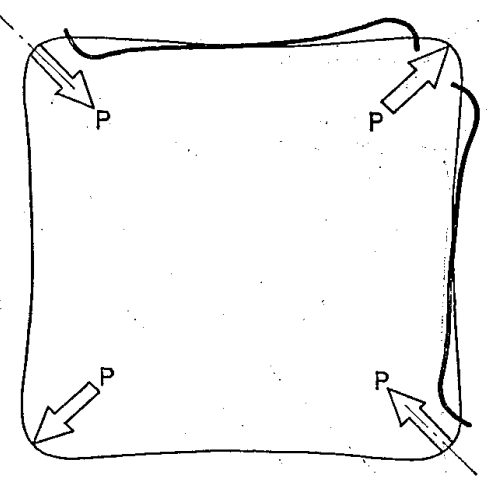

$$
\begin{aligned}
& 0.51,0.5 \text { (P/at) } \\
& \text { 图一9隅に荷重を受ける場合の }
\end{aligned}
$$

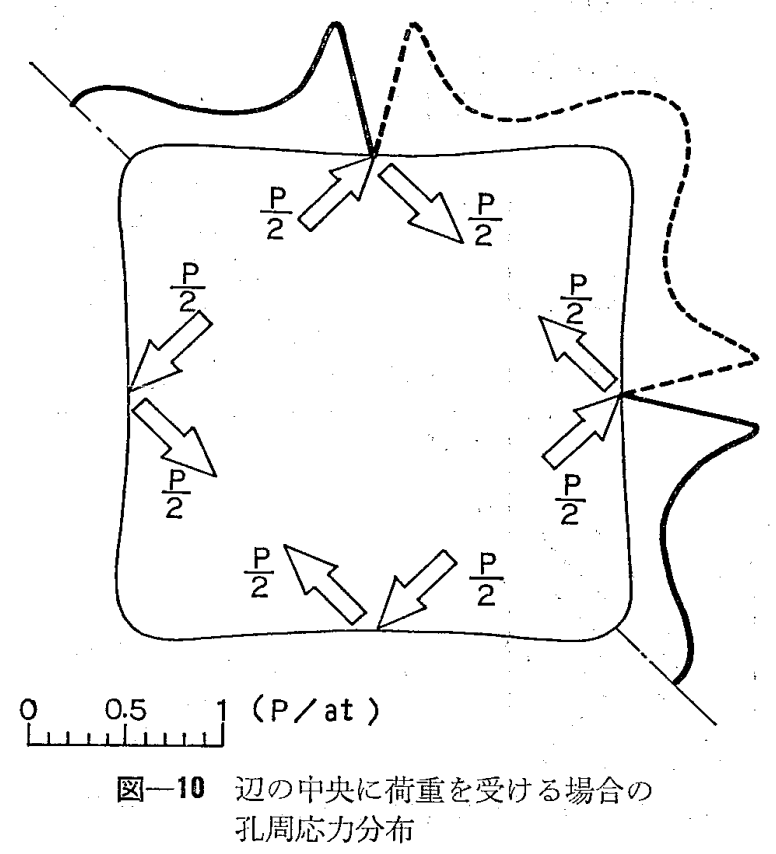

X形筋違の場合には筋違一本当えりの軸力を表わし, 菱 形筋違の場合には同一方向の 2 本の筋違の軸力の和を表 わしているから, 両者とも筋違一本当たりの軸力で比較 すれば，ほぼ同じ値となる。また，図一7 の結果と比較 してみると, 筋違をX形，岁るいは菱形に直交する二方 阊に入れた場合, その負担䩜力の総和は, 一方向に入れ

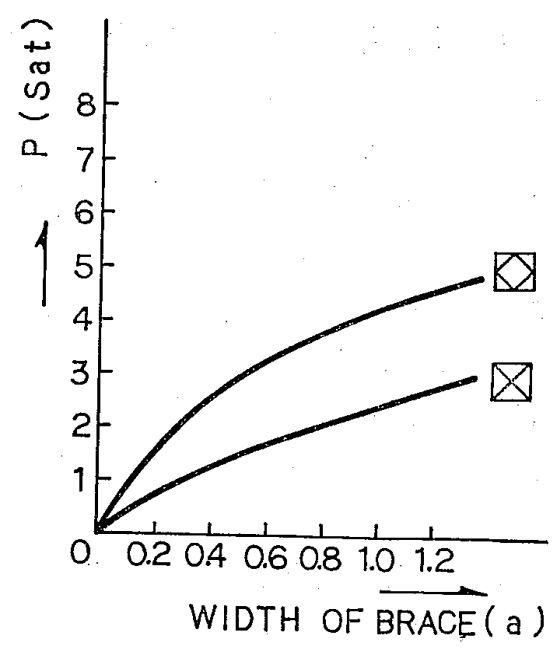

図一11 筋違幅と真担軸力の関係 


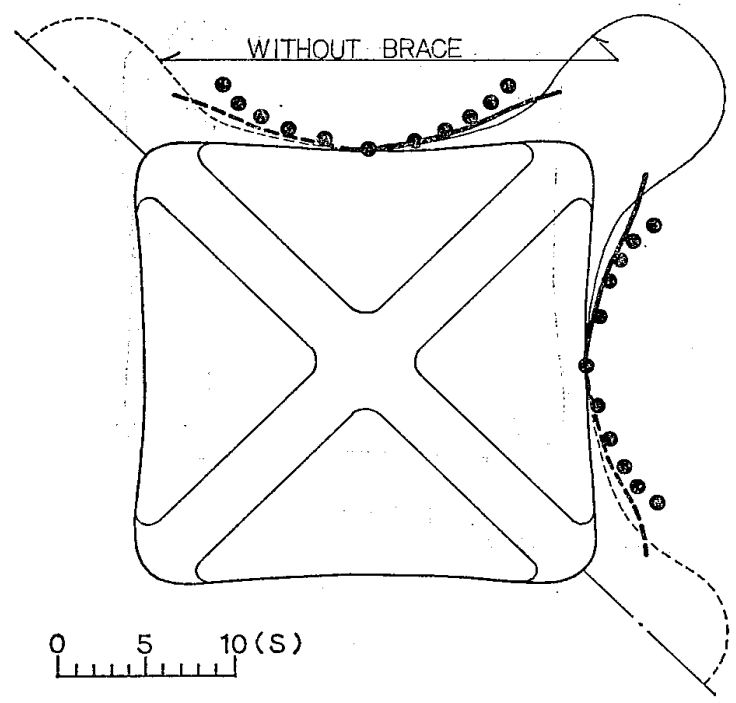

図一12(a) X 形筋違で補強された板の 孔周空力分布

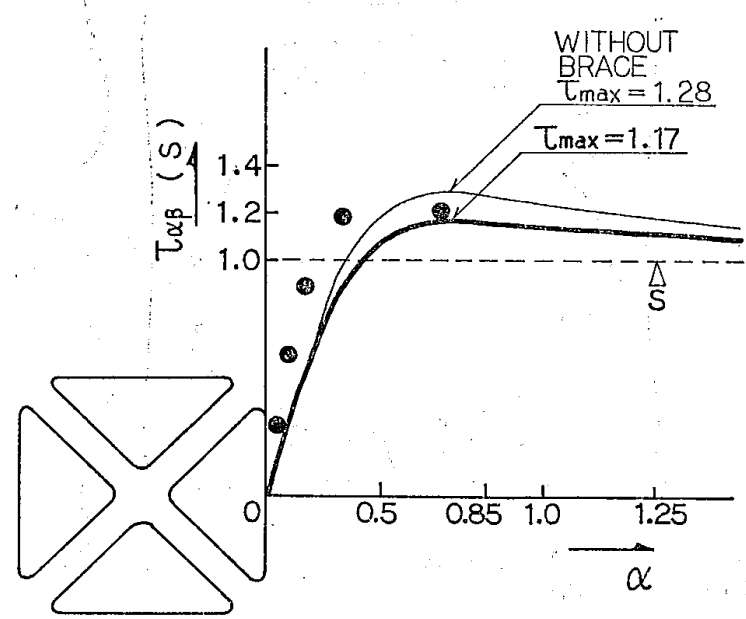

图一12（b） X 形筋違で補強された板の $\beta=45^{\circ}$ 線上のせん断态力分布

た筋違の場合の 2 倍には達しないといらこともわかる。

c) $\mathbf{X}$ 形および贸形筋違の効果

図一12，図一13 は，b) で得られた笳違朝力をもとに して a）の解と絉せん断の解とを重衫合わせ，幅が 0.66 $a$ であるX形筋違および同じ幅の菱形筋違によって補強 された有孔板の応力分布を示したものである。この孔周 応力図を見ると, X形筋違の場合, 筋違端部以外のとこ ろではもとむと応力が小さいために，筋違があっても岕 まり変化がないが, 菱珍筋違の場合には四隅に於いて応 力が減少しておう，その効果注筋違が無い場合の応力に 比べて約 30\% 減となっている。

また，板内部のせん断応力 $\left(\beta=45^{\circ}\right.$ 線上) に関して は，筋違が熙いと最大 $28 \%$ 增大するところを，X形筋 違の場合には $17 \%$ ，そして菱形筋違の場合には $13 \%$ （いずれも筋違幅が $0.66 a$ の場合）の増大に抑えるこ とができる。

\section{§4. 笳違補強の光弾泾実験}

以上で还べを理論的研究の裏付けとして光弹性実験を 行なった。試験体は $11.5 \mathrm{~cm}$ 四方の:5 mm 厚 D.A.P.

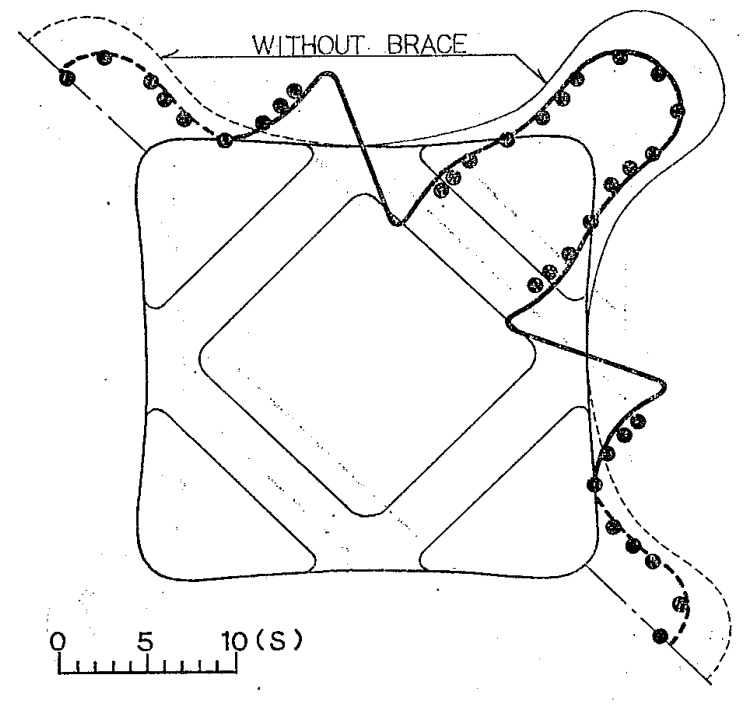

図一13（a）菱形筋違で補強された板の 孔周底力分布

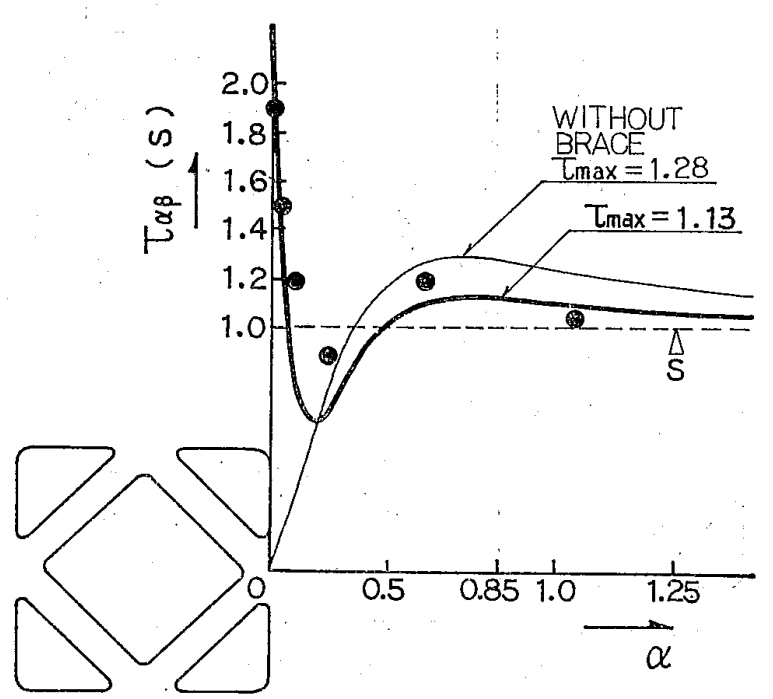

図一13(b) 菱形筋違で補強された板の $\beta=45^{\circ}$ 線上のせ九断灾力分布

板を用い，中央に $2.5 \mathrm{~cm}$ 四方の開口をあけた。この開 口の大きさは (2) 式に於いて $a=0.5 \mathrm{~cm}$ とした場合の c=0 の線によって与元られるものである。また筋違幅 は全て $0.66 a$ 即ち $0.33 \mathrm{~cm}$ とした。また, 板の周辺に は，せん断力を伝えるために，四隅をピン節点としたア， クリル製の枠を設けている。图一14 はその説明図であ る。なお，荷重は，試験体を $45^{\circ}$ 傾けて置いて上から压 縮力を加え，横から引張ることにより純せん断を加えて いる。

写真一3〜6 は，その等色線写真で业る。実験から得ら れた応力分布は, 前節までの理諭解で用いた応力図の中 にプロットにて併記してめる。垁験值は理諭と概ね一致 した傾向を示しているが，実験值の方が一般に高い值と なっている。これは理論が無限板としているのに対し， 実験が有限板のためで方る。なお，夹験で得られた応力 を理諭解と同じ算位に換算するに際しては，理論解で表 われる $S$ の值として，開口を除いた有效断面に於注る 


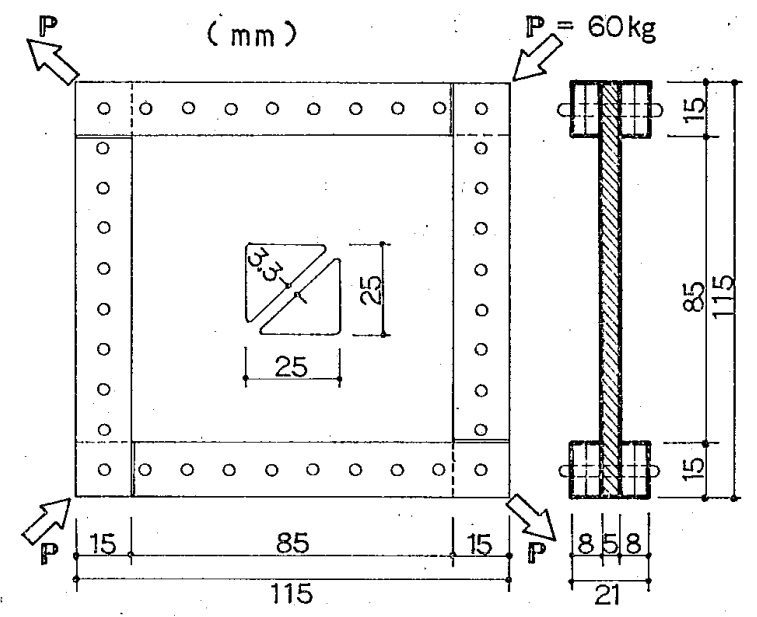

図一14 笳違補強の光弾性実験の試験体

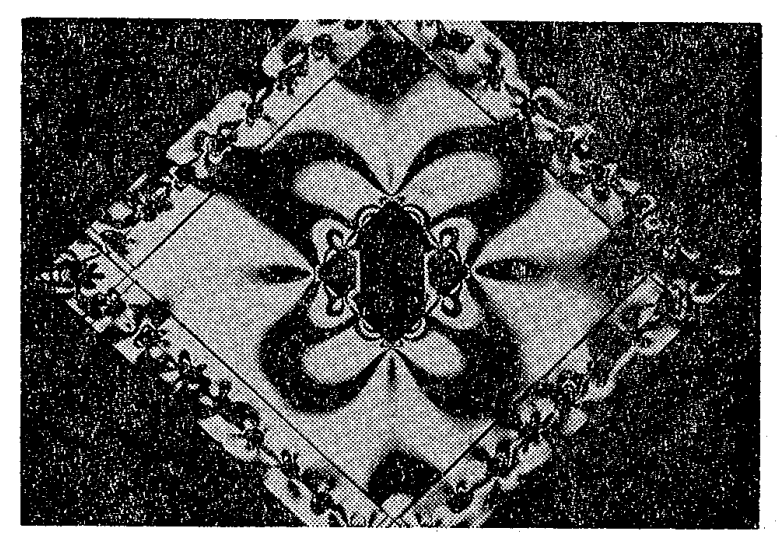

写鼓-3 対角線筋違の等色線

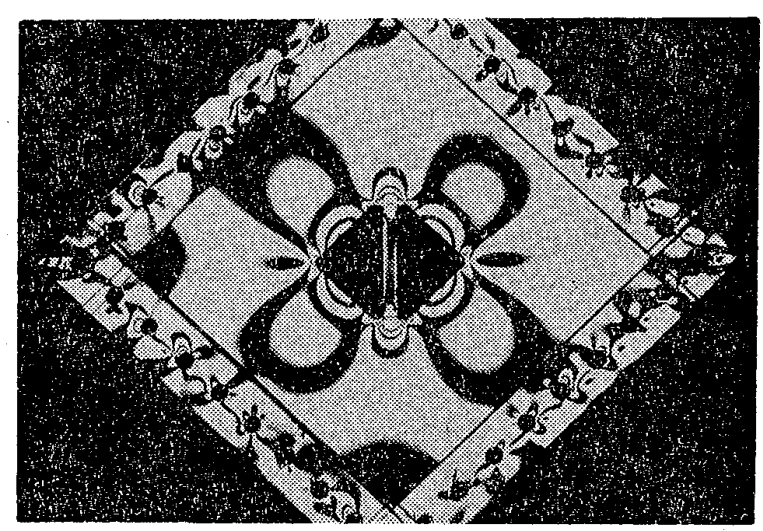

写真一4平行筋違の等色線

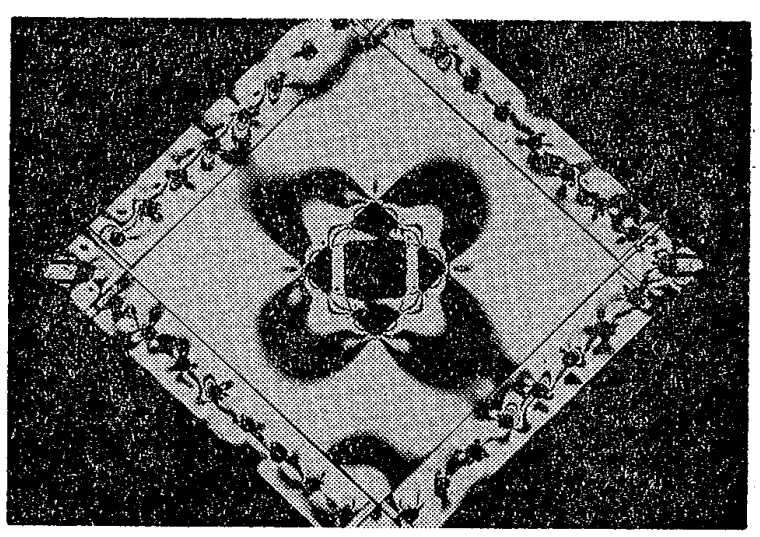

写真一5 X形筋違の等色線

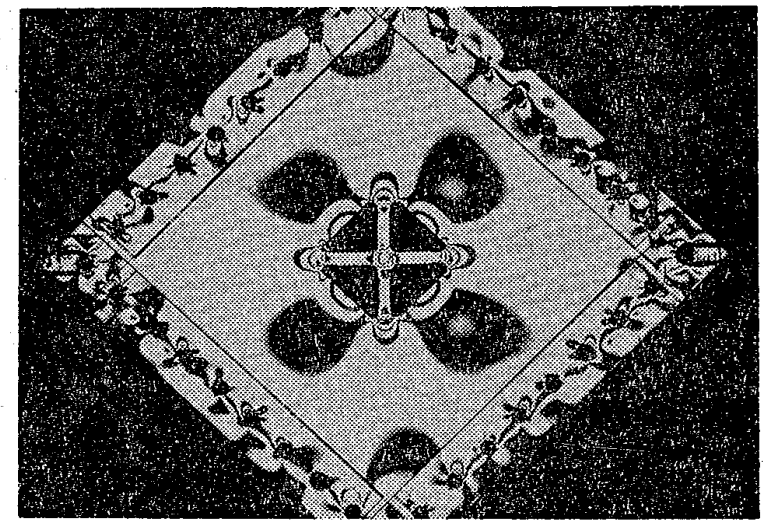

写真一6 - 菱形筋違の等色線

表 : 筋違負担朝力 $P$ の理論值と実験值

\begin{tabular}{|c|c|c|}
\hline 筋違の種類 & 理 論 值 (kg) & $\begin{array}{c}\text { 実 戨 值 } \\
(\mathrm{kg})\end{array}$ \\
\hline 対角線筋違 & 1.95 Sat $=9.2$ & 10.7 \\
\hline 平行筋違 & 3.84 Sat $=18.1$ & 21.4 \\
\hline $\mathrm{X}$ 形竻違 & $1.80 \mathrm{Sat}=8.5$ & 9.6 \\
\hline 菱形筋 違 & 3.41 Sat $=16.1$ & 19.1 \\
\hline
\end{tabular}

平均せん断力, $18.9 \mathrm{~kg} / \mathrm{cm}^{2}$ を用いている。また, 筋遥 の負担軸力に関して, 理論と実験を比較した結果は上表 のとおりとなった。

筋違の軸力についても，試験体が有限板であるために 実験值の方がやや大きな值となっている。

\section{§5. 結 論}

本研究によって得られた結論は次のと晾りである。

A）対角線筋違および平行筋違について

1. 筋違一本当たりの軸力は, 平行筋違でも対角線筋 違でも浪ぼ同じである。

2. 筋違は板内部のせん断応力 $\left(\beta=45^{\circ}\right.$ 線上) の低減 に有効であり，開口によって最大 $28 \%$ 増大すると ころを, 対角線筋違 の場合には $22 \%$, 平行筋違の 場合には $19 \%$ (いずれも幅 $0.66 a$ の場合)の增 大に抑えることができる。

3. 開口周の最大忘力は, 平行管違の場合, 図一8(a) に於いて大上, 右下の 2 つの隅は大きく低減する が，他の 2 つの隅では低減梳としど無い。対角線 筋違の場合は, 図一4(a) の左上, 右下の最大态力 の低隇は小さい。

B） X形㧍よび菱形筋違について

1. 筋違一本当たりの軸力は, X形笳違でも菱形筋違 でもほぼ同じである。また，いずれの場合にも，直 交する 2 方向に入れたからといって, 筋違の総負担 軸力は A) の一方向筋違の場合の 2 倍には達しな w。

2. 板内部のせん断志力 ( $\beta=45^{\circ}$ 線上) の増大は, $\mathrm{X}$ 形筋違の場合には $17 \%$ であり, 菱形筋違の場合に は $13 \%$ である。(いずれも幅 $0.66 a$ の場合)

3. 孔周の応力に関しては, X 形筋違を入れた場合, 
筋違端部を除いた範囲内に於いて虑力があまり変化

しない。一方, 菱形筋違は開口の四隅に於いて孔周

応力の低減に効果的である。しかしながらX形筋違

は，四隅の応力集中箅所に筋違が女ることにより，

他の開口周部分の応力は非常に小さい。

なお，開口隅の変位は，開口だけの時は開口の無い時

の 3.5 倍となるが, 対角線筋違または X 形筋違を入れ

ると, 約 2.5 倍ないしは 2.3 倍（但し, 筋違幅が 0.66

$a$ である場合）となる。

以上要するに, 開口の筋違補強はかなり有効ではある

が, 架構に於ける筋違のように非常に効果的であるとは

言えない。

なお， “後日，板が圧縮力を受ける場合についての研究
を（その2）として投稿する予定である。

\section{謝 辞}

本研究にあたり, 終始適切なる御指導をして下さった 松井源吾教授に媣く感謝致します。

\section{苶考文 献}

1）小野鑑正「材料力学」p. 481

2) Gengo Matsui, "Theoretical Study on Seismic Distribution Coefficient and Steel Reinforcement for a Wall with One Opening Subjected to Earthquake Shear”, 早稲田大学理工学部紀要 15 号 (昭和 26 年 12 月)

3）浅羽隆太郎，“有孔板に於ける岕力に就て”, 造船協会々 報 42 号（昭和 3 年 4 月）

4）坪井善勝, 田治見宏, “関口を有する壁体に就て”，建築 学会研究報告 6 号 (昭和 25 年 5 月)

\section{S Y NOPSIS}

UDC : 624.04

\section{STUDY ON REINFORCEMENT OF SLABS WITH A SQUARE OPENING WITH BRACES}

Part 1 : Stress Distribution under Shearing Force

by HARUYUKI NANBA, Graduate Student of Waseda University, and KATSUTOSHI SATO, Tokyo Electric Power Services CO., LTD., Members of A.I.J.

Slabs in deeply buried structures, such as underground substatuions, are affected by external walls loaded by soil and hydrostatic pressure, furthermore, they must carry shearing forces to external walls under earthquake. For this reason, stresses in slabs take great values and so slabs under the ground are thicker than those above the ground. On making openings in such slabs, the effect of openings on the stress distribution in slabs must be taken into consideration.

As stress concentration generally occurs near an opening, slabs with openings are reinforced there with steel bars. When they are subjected to shearing forces, stress distribution in them are predominantly affected by openings. In order to reinforce such slabs, we can employ the advantage of braces.

In this paper, the effects of braces as reinforcement are examined by obtaining the stress distribution of a slab which has a square openin and is loaded on its inern boundary. This examination is based on the theory of two-dimensional problem in elasticity. Then the magnitude of the effect of a brace can be determined by the condition for compatibility of deformation at the end of the brace. And the theoretical solutions are examined by means of experimental analysis based on photo-elasticity.

Through this study we find that it is considerably efficient to reinforce slabs with openings with braces but not. very efficient in comparison with braces in a frame. 